\title{
POSSIBILITIES OF LAND ADMINISTRATION DOMAIN MODEL (LADM) IMPLEMENTATION IN NIGERIA
}

\author{
S. O. Babalola ${ }^{a *}$, A. Abdul Rahman ${ }^{\mathrm{a}}$, L. T. Choon ${ }^{\mathrm{a}}$, P J M Van Oosterom ${ }^{\mathrm{b}}$

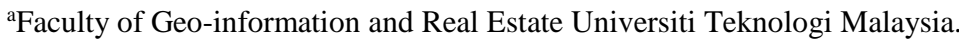 \\ *(omooroloba@gmail.com), (alias@utm.my) (tlchoon@utm.my) \\ bFaculty of Architecture and the Built Environment, Delft University of Technology, The Netherlands \\ (P.J.M.vanOosterom@tudelft.nl)
}

KEYWORDS: LADM, Land Administration, Land Reform, Land use Act, Packages

\begin{abstract}
:
LADM covers essential information associated components of land administration and management including those over water and elements above and below the surface of the earth. LADM standard provides an abstract conceptual model with three packages and one sub-package. LADM defined terminology for a land administration system that allows a shared explanation of different formal customary or informal tenures. The standard provides the basis for national and regional profiles and enables the combination of land management information from different sources in a coherent manner. Given this, this paper started with the description of land and land administration in Nigeria. The pre-colonial, colonial and post-colonial era with organization structure was discussed. This discussion is important to present an understanding of the background of any improvement needed for the LADM implementation in Nigeria. The LADM, ISO 19152 and the packages of LADM was discussed, and the comparison of the different aspects of each package and classes were made with Nigerian land administration and the cadastral system. In the comparison made, it was discovered that the concept is similar to LADM packages in Nigerian land administration. Although, the terminology may not be the same in all cases. Having studied conceptualization and the application of LADM, as a model that has essential information associated with components of the land administration. Including those on the land, over water as well as elements above and below the surface of the earth and discovered that the standard is suitable for the country. The model can, therefore, be adopted into Nigerian land administration system by mapping in some of the concepts of LADM.
\end{abstract}

\section{INTRODUCTION}

The land is the most valuable resource without which man could never exist and on which his continued existence and its progress. It is the natural gift of nature; the extent cannot be extended by any means because it is fixed. The demands, and it's usage keep increasing every day because of the increase in demands. The space to build, the space to construct and to live is becoming unavailable. Had made man to build up more interest in the way it should be managed. The government of the day wants to acquire the land for the developmental purposes. The community and individual land is needed to build personal houses. Land use and the interest in land is becoming complex as a result of urban development. The immediate solution and remedies are the land administration system. Land administration system seems to be the only system man can engage to solve this rural and urban cities complexities problem. Land administration, according to (Dale and McLaughlin 1999) is the process of regulating land, the use of property development and conservation of the land. It also includes the gathering of revenues from the land taxation, sales of the land and the resolving of the disputes on the ownership and use of the land. However, the main objective is to create an open and secure market economy where land is transformed into means and economic commodities.

However, the conventional financially viable thoughts consider land as a factor of production as labour, capital, and entrepreneur. Land is no longer be referred to as the seed bearing surface or the physical structure placed on it only but as a space that contains activities which are artificially defined and delineated by surveys and structured from the natural world. Land policies in developing a country of the world have recently attracted attention. The major reason cannot be over emphasis; first, there is recognition that enhancing smallholder productivity is critical for sustainable and broad-based growth as well as poverty reduction. The demand for land has greatly increased with population growth, urbanization and overall trade and industry development. The increase in the higher value of land makes land registration more rewarding. Thirdly, in decentralized scenery land administration helps to provide public goods and improve government finances and help to develop rural areas on the basis of more than just agriculture.

The land administration system has undergone series of birth and rebirth over the years in many developed and developing countries. Nigerian being a developing country also developed in their land administration system. , It is designed to support transactions of rights of people, individual, formal and informal, rural and urban society about land. The information related to the land matter is also is made available to everyone involving in land transactions at any point in time. Access to this information grants safety of the transaction and gives the possibility to identify the transaction (Siejka et al. 2014). Given this, the International Federation of Surveyors (FIG) founded in 1878 in Paris. FIG is an International organization representing the interests of Surveyors worldwide, in 1994 mandated the (Commission 7 Cadastral and Land Management working group) to work on the existing cadastral, and the vision for future cadastre system (Cadastre 2014, FIG1998) (Jürg Kaufmann and Steudler 1998).

Consequently, the process of development in cadastre 2014 gave birth to Core Cadastral Domain model (CCDM) and Land Administration Domain Model (LADM) (Oosterom et al. 2006), (Dinao and Coetzee 2013). LADM was formally published on the $1^{\text {st }}$ of December 2012 by International Standard ISO19152. (Oosterom et al. 2013). Land Administration Domain Model (LADM) was approved by the International standard organization of ISO 19152 technical committee TC/211 for 
Geographic Information/Geomatics. It was designed as a standard for all land registration and transactions within the country and countries or local and localities. LADM is an abstract conceptual reference model that enables the concerned party or parties to communicate on the same platform based on a shared vocabulary. LADM supports the development of the application software and data quality management in land administration system (Oosterom et al. 2012). It is an extendable, efficient and effective domain that expert in other countries can develop packages based on LADM for their countries.

Therefore, this paper started with the introduction and description of the pre-colonial, colonial and post-colonial era of land and land administration system in Nigeria. In section 2, land administration system and the organizational chart of the ministry responsible for land, survey and housing was discussed. Section 3 discussed land use Act of 1979, the postcolonial era, the shortcoming of the land use Act and the need for land reform, the terms of reference of the Presidential Technical Committee on Land Reform and the importance of land reform policy. In section 4, a country profile for Nigerian LADM was discussed with the LADM packages and its relevance in her land administration system also in the section, we identified the similarities and differences between the content of LADM and Land Administration/Cadastral system. Section 5 is the conclusion and the future work.

\section{LAND ADMINISTRATION SYSTEM IN NIGERIA}

Nigeria covers an area of $923,768 \mathrm{~km}^{2}$ on the coast of West Africa. The land use pattern comprised of arable land of about $33 \%$ of the total land area. The pastures land covering $44 \%$, permanent crops covering $3 \%$, forest and woodlands $12 \%$ and others $8 \%$. Thus, the land is still the main asset of rural Nigerians with over $80 \%$ being peasant farmers.

\begin{tabular}{|l|l|l|l|}
\hline S/no & Category & Area (Km2) & $\begin{array}{l}\text { Percentage } \\
\text { of Total } \\
\text { Land }\end{array}$ \\
\hline 1 & Arable land & $304,843.44$ & 33 \\
\hline 2 & Pastures land & $406,457.92$ & 44 \\
\hline 3 & Permanent crops & $27,713.04$ & 3 \\
\hline 4 & $\begin{array}{c}\text { Forest and } \\
\text { Woodlands }\end{array}$ & $110,852.16$ & 12 \\
\hline 5 & Others & $73,901.44$ & 8 \\
\hline & Total & $\mathbf{9 2 3 , 7 6 8}$ & $\mathbf{1 0 0}$ \\
\hline
\end{tabular}

Table 1. Land usage category in Nigeria

Nigerian, land administration system, is a very direct copy of (Queen) Her Majesty's Land Registry in London (United Kingdom) since 1862 (Fadahunsi 2011). Its purpose was to provide a simple, safe and economic system of land administration and transfer in England. It was not founded to create a general-purpose land information system for the public at large, but a system whereby the interests of people, individual or corporate bodies owning land or legal interests of people, individual or corporate bodies owning land or legal interests in land area protected.

Land administration in Nigeria is based on the British system, which came into existence in 1862 but has been in use in Nigeria since 1924. The system involves defining parcels of land spatially (i.e. the boundaries are defined by a survey that shows accurate measurements from one or more permanent monuments).

A plan is drawn that shows the parcel is filed in the Titles Office, which issues a Certificate of Title, and a copy of the certificate is kept. The Certificate of Title, therefore, describes the parcel and its tenure, the name(s) and address(s) of the owner(s) and specifies the mortgages and other interests affecting the ownership. The resultant certificate, the title in property cannot be made void, defeated or canceled by any past event, error or omission in the title. Because the government warrants that no interest burdens the title other than those on the certificate. The current system of land registration creates a lot of records about owners and their properties which is entirely paper-based (Fadahunsi 2011). The records being kept include the title number, maps and parcels index, first registration, transfer, land certificates, mortgage by deposit, abstract book, filed documents (in cases of adjudication) and names index.

\section{Land Tenure System}

In Nigeria, Land administration system started before the colonial era. The pre-colonial land administration system in Nigeria was characterized by adjudication and appropriation by the might of warfare, rulership in which warlord and Kings carved out dominions for their followers (Atilola 2010). The followers and their family occupied the area carved out for them for that period. Also, the land was used for farming and grazing purposes. Because of this, lands are held by the villages, families and communities. The individual having usufructuary right because they are PartyMember extended it to their lineage. The boundaries are defined using natural structures such as a tree for each family or community. The case in the northern part of Nigeria is not the same as the southern part. The nomadic Fulani are cattle rare, they rare their cattle over a large expanse of land and found their settlement without defining any boundary. After the Fulani Jihad war, the Emirs have the ultimate title to land.

During the colonial era, there were multiples of land tenure system because Nigeria was divided into colonies and protectorates by the colonial master. The landholding system was freehold; this caused lots of conflicts between the traditional land tenure system and the colonial freehold system that has given rooms for the European trading to acquire land. In the North, the Emirs are appointed and exercised proprietorial rights that gave them the power of land holding. However in 1910, the control and administration of land was given to the Governor in the interest of the indigenous population. The amalgamation of the Northern and Southern protectorate brought about changes when the whole country was finally formed into states. Each state inherited the land tenure system from the Region where the state was created.

Today, Nigeria occupied $923,768 \mathrm{~km}^{2}$ on the coast of West Africa. It is located on latitude $4^{\circ}-14^{\circ} \mathrm{N}$ and longitude $2^{\circ}-15^{\circ} \mathrm{E}$ (Njepuome. 2011), Nigeria has 36 State with a Federal capital territory which is the seat of the federal government. There are 774 local Governments with over 250 ethics group speaking over 400 different languages. The whole nation is divided into 6 Geopolitical Zone used for developmental planning and political appointment. The land administration and cadastral practice in each State of same geopolitical Zone are similar because of their geo- political affiliation and integration (Babalola et al. 2015). 


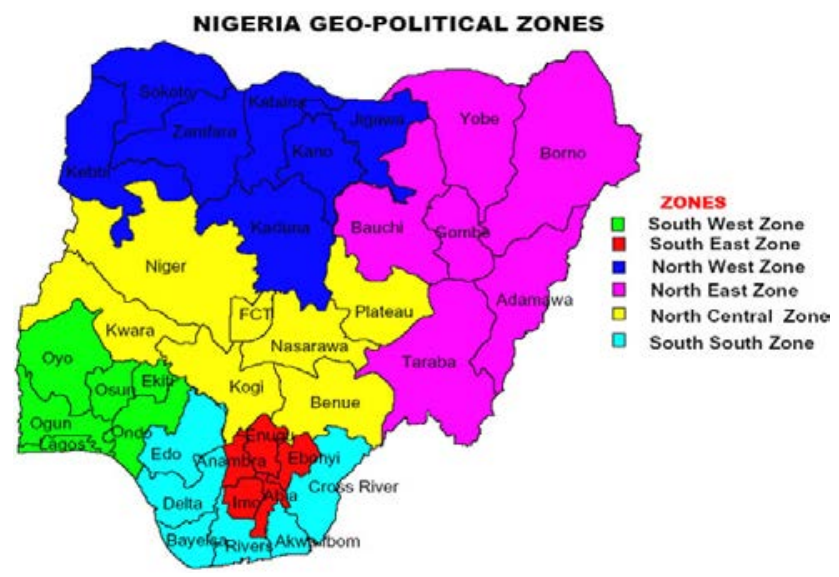

Figure 1. Map of Nigeria. Office of Surveyor General of Nigeria (Babalola et al. 2015)

The pre-colonial land tenure system in Nigeria was so complex because of its ethnic, geographical and cultural diversity. Each of ethnic groups and regions and zones practiced different customary systems. The colonial government started the formal documentation of rights and interests in Lagos protectorate in 1863 since there were no formal records of the land transaction before the colonial period. It was extended to other parts of the country in 1894. The land was considered the basis for housing, food and employment and was not considered a purchase as granting freehold rights. The colonial government Crown by virtue of invasion, coercion, treaty, cession, convention or agreement acquired lands. Such lands became state land in postcolonial period (Chigbu and Klaus 2013). It was the Native Land Acquisitions of 1900 and the Lands and Native Rights Ordinance of 1916 that established formal land tenure systems in Nigeria (Chigbu and Klaus 2013). It was not the case in northern Nigeria, where a semi-feudal system prevailed. The colonialists later declared all land in the northern part of Nigeria as public land by creating ordinances to empower their administrators to carry out expropriation rights over such lands. After Nigerian independent on 1st October 1960, there have been series of decrees and laws in all aspects of national issues including land. In 1962 under the land law Act, the absolute ownership rights of the natives over land were subjected and restricted to the right of occupancy, that is a limited right of use over land for a determinable period. The control, management and administration of land were transferred from the emirs to the chief executive (the Governor) of the northern and southern protectorate.

\section{Government Land}

The Governor is holding the land in trust for the people and controls the use of land in every state of the federation. The Land Use Act of 1978 empowered local, state and federal government administrators to regulate the occupancy, use and transfer of land in the name of greater equality and national economic development. Land Used Act empowers the government to acquire lands from the individual owners and pay compensation for the acquired land. However, the land are used by the government on behave of the people for developmental purposes.

\section{Land Taxation}

Land taxation aimed at generating public revenue, providing a stable fund for the acquisition of land for banking. Also servicing land by facilitating the efficient utilization of land and providing incentives for appropriate land uses. The laws empower the State and local authorities to collect taxes and stamp duty, estate duty, and rates. Land taxation in Nigeria is carried out with the main intention of either levying property taxes (rates) or buying and selling of land especially in the case of a compulsory land acquisition.

\section{Land Ownership}

The law vests ownership of all land within a state (except those vested in the Federal Government or its agent) in the Governor of the state. He holds land in trust for the people and allocates same as far as the urban area is concerned. This allocation may be to individuals and corporate entities for residential, commercial, agricultural and other purposes allowed by law. Land located in rural areas is under the control of local government authorities. The documentary evidence of ownership in Nigeria is called title deeds or title documents. Ownership of land before the Land Use Act was either by the settlement. With the promulgation of the Land Use Act, ownership acquired by the above methods became extinguished and vested in the Governor of the state. Freehold interest acquired prior to the Act became convened to leasehold. A lease granted by the Governor is usually for 99 years, and it is subject to review upon expiration. The terms of the lease are under the Land Use Act, contained in a Certificate of Occupancy (C of 0) granted by the Governor.

\section{Land conveyance}

Land conveyance or land transfer is the process of moving the legal ownership of land from one person to another. It is achieved either by agreements (selling, buying, leasing and mortgaging) or by social events (death, birth or divorce). It can be either freehold or leasehold. The procedure is usually initiated by a transferee who signs the transfer agreement together with the transferor in the presence of a witness. The process of land transfer starts when the parties to a land transfer enter a sale agreement stating the terms of transfer that include the sell price, payment method, names and addresses of the buyer and seller including the location of the land. The sale agreement is signed by the parties in the presence of an advocate of the high court. After verifying the duly signed forms and the necessary consent by the Land officers, the Land officer affects the transfer in the Register and the process of issuing a title deed to the buyer begins.

\section{Land Registration and Titling}

Land registration plays an important role in a nation, especially when they function effectively. Every country of the world possesses country specific land registration regulations and laws. A land registration system in Nigeria involves three principal systems of recording the rights/ownership to the land. i. Private conveyance

ii. Registration of titles iii. Registration of Deeds

The title is, however, a description of a land parcels, details, and description contain within usually includes the followings:

1. Description of location or boundary, bearing and distances, survey description, meters and public land survey system reference, plot number in platted subdivision coordinates, etc.). 2. The Method of conveyance warranty deed and quit claim, etc. The financial implication of providing its essential foundation a plan of sufficient accuracy of the area whereby every parcel registered can be clearly identified has delayed its establishment in some countries.

However, it is important to note that, 
- Deeds are instrument that entails registration of land transactions and interest with a public authority (Register of Deeds)

- Land transaction is between individuals or corporate organization

- Registration is voluntary though typically done to support a claim to land and create a land market.

- Grantor and grantee (conveyed from, to) organized records in a systematic classification basis for ease of retrieval and dissemination.

The title is an abstract term used to refer to records, documents, and acts that confirm ownership. It establishes the quality of right in real estate being conveyed from the seller to the buyer. Title documents may be a certificate of occupancy, a registered conveyance, or Deed of Assignment, Power or Attorney, mortgage, surrender, and release, etc. Security of title to land is very important as it is often really difficult to obtain investment funds and venture capital without it. It facilitates the proper exploitation of lands as a source of wealth and economic success to the people of Nigeria. It assures social and economic gain of securing rights in land. It facilitates private land ownership. It helps to secure private rights in land. In Nigeria, land registers and public land records ensure that information can be quickly and widely accessed. It helps in developing a secure financial sector. Land registration makes possible quick and sure procedure for creating and securing mortgages. It provides a sound basis for land management whether it is for developing sustainable agriculture, managing the rapid growth of cities or protecting the environment, etc.

The problem of land title registration came from some provisions of Land Use Act of 1978, which is the law regulating the administration of land in Nigeria. The main provisions of the Act which affect the land alienation and conveyance are stated bellow.

\section{Land use planning}

Land use planning is one of the surest ways in which land is been managed to achieve remarkable success in land administration. Land management and use of land are an essential land administration process. Although it differs from one country to another. In Nigeria, the physical planning and development plans and carried out by Ministry of physical planning regarding the survey plans as been drawn by the surveyors. They are correctly plotted to scale showing the existing plot and their dimensions and boundaries, the areas of the plots, the addresses and locations, reference and registered number of the plot. All the adjacent plots and road system both existing and approved are shown.

\subsection{Organizational Chart}

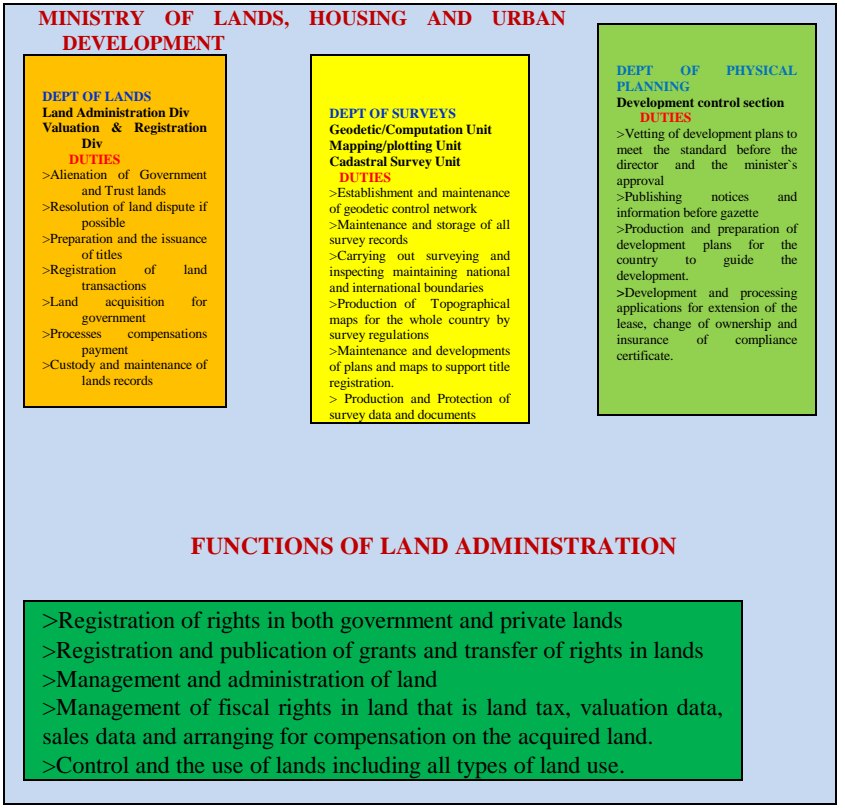

Figure 2. Organization structure of the Ministry and their duties.

\section{LAND USE ACT 1979 (POST-COLONIAL ERA)}

Survey regulations and laws were made to guarantee a uniform and standard survey practice and to control the surveying profession in Nigeria. Before the legislation of the Land Use Act of 1978, there were different methods of land registration recognized which include the statutory right of occupancy, the customary right of occupancy and title registration.

The northern regional government created a law that subjected all land in that region to the control of their governor for the use and benefit of all northern people. In an attempt to stop the contrasting land tenure systems and the attendant litigations, fraudulent and deceitful practices, with difficulty being experienced by governments in getting land for public use. The Federal Military Government promulgated the Land Use Decree (now Act) of 1978. The Act "whereas it is in the public interest that the rights of all Nigerians to the land of Nigeria be asserted and preserved by law; and whereas it is also in the public interest that the rights of all Nigerians to use and enjoy land in Nigeria and the natural fruit thereof in sufficient quantity to enable them to provide for sustenance of themselves and their families should be assured, protected and preserved........all land comprised in the territory of each State in the Federation are hereby vested in the Governor of that State and such land shall be held in trust and administered for the use and common benefit of all Nigerians...." (Federal Republic of Nigeria 1978) With these, the Act put the land in the custody of the state so as to make land delivery for development quicker. This Act, therefore, gives the state governors powers to grant statutory rights of occupancy of fixed periods in urban areas. And the municipal chairmen (mayors) powers to grant the customary right of occupancy on land in the rural areas. With the operational and principles of the Land Used Act (LUA), land tenure is nationalized in Nigeria. For the first time in Nigeria, the Act unifies the land tenure systems all over the country in addition to nationalizing land in the country's geographical Space (Atilola 2010). The other objectives of the Act as recorded by (Atilola 2010), are as follows: 
To remove bitter controversies and litigations that usually arises over title to land.

To streamline and simplify the management and ownership of land in the country

To assist the citizenry, irrespective of his/her social status, to realize his/her ambition and aspiration of owning land

To enable the government to bring in control into the use to which land can be put in all parts of the country and facilitate planning and zoning programs for a particular use.

To curtail the activities of land speculators and remove the undue influence, that certain traditional rulers have on land.

The LUA failed to meet the potential promises due to various technical, intuitional, social and political reasons.

\subsection{The Short Coming of Land Use Act and the need for Land Reform in Nigeria}

$>$ Each New Government since the promulgation of the Act had exhibited a lack of support for the implementation of the Act to make it succeed.

> The State Governors and local government Chairmen, (the trustees) had been characterized by a lack of transparency in matters.

> The Act has not succeeded in removing the doubts in title to land; it does not protect small-scale peasant farmers who continually lose their farmlands through land acquisition for urban expansion and large-scale acquisition without paying adequate compensation.

$>$ The requirements for obtaining the statutory right of occupancy or local government for customary rights of occupancy before the transaction in the land is cumbersome and expensive.

> The existing freehold title to land was abolished and limits the title that can be granted under it to leasehold interests of 99 years. In this sense, the allottees of state land and owners of properties of the Certificate of Occupancy became tenants of the State.

According to (Atilola 2010), it is the current dysfunctional nature of land administration dynamics in Nigeria, and concerns arising from its unproductive nature that informed the need to provide a better strategy that will make Land Administration system work and also provide benefits to all citizens of Nigeria.

\subsection{Land Reform in Nigeria}

The inadequacies and failure in the implementation of LUA led to agitation for the review by many stakeholders. In a bid to improve the land administration system in Nigeria, the Nigeria Federal government established a Presidential Technical Committee on April $2^{\text {nd, }}$ 2009. To undertake the reform of all land tenure situation to address various problems emanating from Land Use Act of 1978. The reform prepared to correct this and provide registrable titles to all land owners in the country by reviewing land laws to ensure equitable use of the land assets for economic development (Mabogunje 2007).

The land reform committee (PTC) terms of reference includes; Determining the individual possessory rights using the best practices and most appropriate technologies and methods to determine the process of identification, locations and registration of title holdings.
Collaborating and providing technical assistance to State and Local Governments to undertake land cadastral nationwide.

Ensuring that land cadastral boundaries and title holdings are demarcated in such a way that communities, hamlets, villages, village areas, towns, will be recognizable.

$>\quad$ Encouraging and assisting the State and the Local Governments in establishing an arbitration/adjudication mechanism for land ownership conflict resolution.

Making recommendations for the establishment of a National Depository for Land Title Holdings and Records in all States of the Federation and the Federal Capital Territory.

Making recommendations for the establishment of a mechanism for land valuation in both urban and rural areas in all parts of the country.

Making any other recommendations that will ensure simplified and effective, sustainable and successful land administration system in Nigeria.

Land reform in Nigeria is a milestone in the development and implementation of Land Administration Domain Model (LADM) in the country land administration system. The land reform committee (PTC) was charged with the duties of making a road map for improving the existing technical and institutional, administrative and legal framework of the cadastral system with a view to developing land market for the Federation. Furthermore, to ensure efficiency in our national land administration system, the Federal Government has established a computerization program for all lands held and allocated by Federal Government under the Federal Land Information System (FELIS). Similar computerization projects have also been established by the authorities of the Federal Capital Territory (Abuja). Also the governments of Lagos, Enugu, Abia, Benue and Ondo and other states of the federation for records of lands allocated to their territories (Oboli and Akpoyoware 2010). To facilitate the harmonization of the land administration system and practices nationwide, a National Technical Development Forum (NTDF) on Land Administration was inaugurated by Government. To hasten property rights transfer, the former Federal Ministry of Environment Housing and Urban Development introduced a band of the value system for different categories of landed properties to reduce transaction time.

Consequently, the attribute of the land and building, land use, the information relating to the meaning of land and property. Legal, information relating to ownership, rights, restrictions and responsibilities that are related to LADM will be taking care. It means PTC will establish a National Depository for title holdings in all states of Nigeria, the Federal Capital Territory and create an instrument for land valuation in both urban and rural areas in Nigeria. It will serve as a data bank for multipurpose cadastral in each state and the whole country. In other word, each state in the federation will be able to communicate with each other and the federal capital since the whole country operates the same land administration system. It is one of the fundamental requirements for land administration domain model (LADM) conformance for the country profile. 


\section{A COUNTRY PROFILE FOR NIGERIAN LADM}

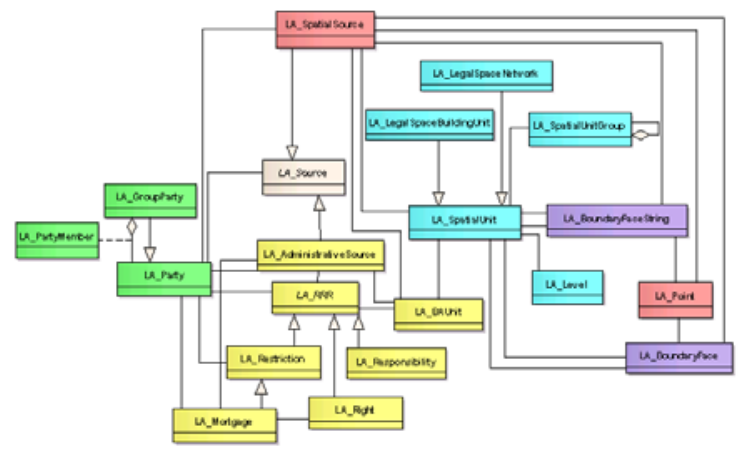

Figure 3. The Land Administration Domain Model (Lemmen and Oosterom 2013).

\subsection{LADM Packages}

The followings are the three packages in LADM with one subpackage

The Party Package

The Administrative Package

The Spatial Package

The sub-package is the Surveying and Spatial Representation

An overview of the LADM packages, its basic classes, and current land administration system in Nigeria is made in this section. LADM been an International Standard (Lemmen 2012) provides an abstract conceptual model of the packages related to parties (people and organizations). Basic administrative units rights, restrictions and responsibilities (RRR) ownership rights. Spatial units, (the building legal space, utility networks, and parcel). Spatial sources surveying and spatial representations (geometry and topology).

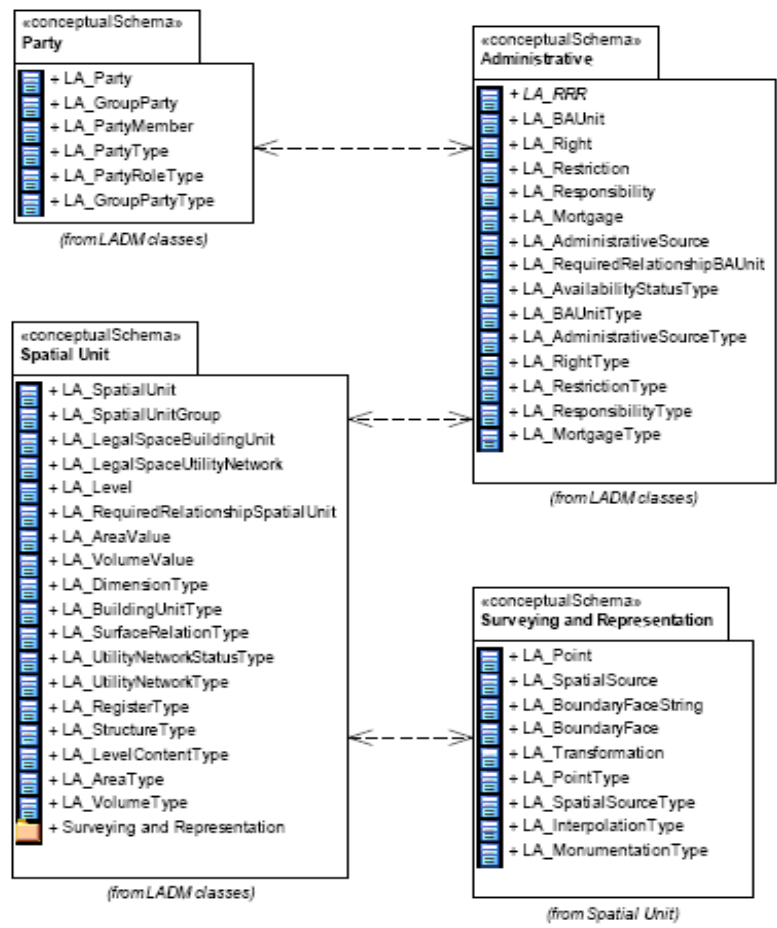

Figure 4. Basic classes of LADM: (Lemmen 2012)

\subsection{The Party Package}

A party could be a natural or non-natural person (individual), organization (group of individual) or a juridical person that composes an identifiable single legal entity that plays a role in a right transaction. LA_Party is the main class of the Party Package with its specialization LA_GroupParty (Lemmen 2012). Any number of parties is a group party, forming a distinct entity, a village community or a tribe with an optional association class LA_ PartyMember. A party member is an individual registered, recorded and identified as a member of a group party. Therefore, LA_PartyMember is an association class between LA_Party and LA_GroupParty. There are external classes; those external classes has references from LA_Party. In Nigerian land administration system, the party can be identified as a natural or nonnatural person(s) in the title deed of the land registration system. Also, the GroupParty and PartyMember can be identified. Therefore, the NG_ prefix is proposed for the classes in this package for the country profile (NG_Party, NG_GroupParty, and NG_PartyMember). Another Party identified is in the land registration to obtain the Certificate of Occupancy ( $\mathrm{C}$ of $\mathrm{O}$ ) in Nigeria. In the certificate of ownership other than the proprietors. Registered Surveyor (survey plan), the Governor or the Commissioner of Lands as the case may be, and a lawyer is also identified in other documents in land administration. All attributes of this package are applicable in the land administration system of Nigeria.

\subsection{The Administrative Package}

LA_RRR and LA_BAUnit are the core classes of the main Administrative Packages. LA_RRR has three classes as specializations (LA_Right, LA_Restriction, and LA_Responsibility). LA_Right; a right is an entitlement to own; it is an action or activities that a system participant may use an associated resources (Zulkifli et al. 2013). A right in any case can be formal or informal use right; it may be overlapping, or may be in disagreement (Lemmen 2012). LA_Restriction; The example of restriction may be disallowing building within 200 meters of a fuel station; or giving specific meters in which a building can be erected along the major roads. Restrictions, usually, remain valid when the right to the land is transferred or mortgaged. LA_Responsibility, it is a formal or informal obligation to do something for example. The responsibility to clean a ditch, to remove a snow-free pavement, to keep save the survey beacon in around owns land parcel, to maintain a monument (Lemmen 2012). LA_BAUnit is an administrative entity of zero or more spatial units against in which one or more rights, responsibilities or restriction are associated as included in Nigerian land administration system (Choon and Seng 2013). The three specialization classes of the administrative package, LA_Rights, LA_Restriction and LA_Responsibility can be identified in the Nigerian land administration system. Rights are given to parcel owners formal or informal as an entitlement to own. Restrictions are disallowing or limiting certain rights to ensure safety, an example is disallowing building within 200meters of a fuel station. While Responsibilities are an obligation to do, for example, to keep survey beacons and maintains a monument. These are part of the content of note that is kept in the register as encumbrance and rights adversely affecting the parcel. The BAUnit can be considered currently as an abstract in Nigeria land administration because the land parcel is the Baunit in land registration. The terms used in the Nigerian land administration system may not be the same with that of LADM as condominium etc., but the model provides a starting point and a useful template to develop Nigerian system. 
Or in any case an optional specialization version may be considered. The prefix NG_Rights, NG_Rectrictions, and NG_Responsibilities may be considered for Nigerian country profile in an administrative package of LADM.

\subsection{The Spatial Unit Package}

A spatial unit is a single area or multiple areas of land and water or volume single or multiple of space with the main core class LA_SpatialUnit (Lemmen 2012). In other words, a spatial unit can be a parcel, grouped into two forms of sub-spatial units or sub-parcels; this is the grouping of spatial units into parts. The spatial unit group in the case is any number of spatial units (an entity) a municipality is an example of the spatial unit group. In Nigeria, the Spatial Unit class can be identified in the cadastral plans/maps used in land registration. Cadastral plans/maps from which land parcels are plotted can be identified on the basis of land registration, the information is available on every cadastral plan/map local and state where the parcel are located. The spatial units can be referred to as the specialization of building unit and utility network. They are identifiable on the Nigerian cadastral plans/maps either as a sectional properties or easements.

\subsection{Surveying and Spatial Representation Sub-Package}

Surveying and Spatial unit represent sub-package used for the identification and representation of the spatial units. Spatial units are structured such a way to support the creation and administration of Basic Administrative Units. The Spatial Unit Package has one sub-package of Surveying and Spatial Representation with classes as LA_Point, LA_BoundaryFaceString, and LA_SpatialSource. Surveying involves the identification, analysis and the acquisition of point location of boundaries of spatial units (Siriba and Mwenda 2013). Boundary represents the limit of a spatial unit that can be represented as points (LA_Point), polygons (LA_BoundaryFaceString), and polyhedral (LA_BoundryFace) surfaces for $3 \mathrm{D}$ features. A plan that provides facts about the spatial representation of one part or more spatial units is called a spatial source. That may be the final formal documents or all documents related to the survey. Examples are an orthophoto Geodetic control points, a field survey sketch, and satellite imagery with evidence on the location of boundaries collected from the field (Lemmen 2012). A spatial source may be paper based documents that may be scanned or official or unofficially registered survey plan or an aerial photograph. It is an integral part of the land administration system.

LADM is considered in this context as digital cadastre that is the major focus of land reform in Nigerian land administration system. The Nigerian cadastre system is made up of different types of maps and plans. In the survey plans, land boundaries are plotted from the coordinate of each land parcel that is made from lines when they are joined. In recent time, field data are acquired digitally and plotted digitally to obtain digital cadastral maps. However, surveying and spatial representation is identified in Nigerian cadastral and land administration system. Therefore, NG prefix for the classes may used thus; NG_Point, NG_BoundaryFaceString, and NG_SpatialSource. In Nigerian context, Surveying also involves the identification, analysis and acquisition of the point (data) location of boundaries of spatial units.

\subsection{External Classes}

External classes are classes that are outside the scope of LADM, but the data set that are expected from this external source are provided for in the stereotype classes of LADM. The physical utility network data, the taxation data, address data, evaluation data, external databases with party data, land use data, land cover data and archive data are outside the scope of LADM. These classes are as follows: ExtPhysicalUtilityNetwork, ExtTaxation, ExtAddress, ExtParty, ExtLandUse, ExtLandCover, ExtValuation and ExtArchive (note: they do not have LA_prefix). They do give an exact definition of what LADM is expected of these external classes (Oosterom et al. 2012). These are also seen in the Nigeria land administration system except ExtPhysicalUtilityNetwork, which is not popular in its land administration system.

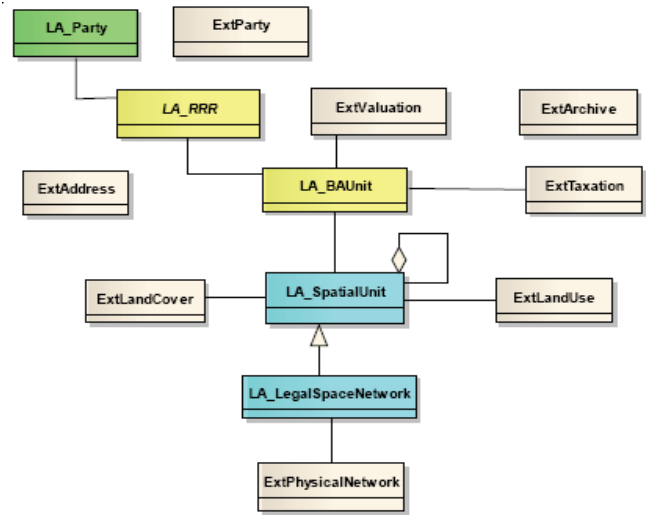

Figure 5. LADM and External Classes: Source: (Oosterom et al. 2013)

\subsection{Special Classes}

The historical data in the database is managed and maintained in LADM by the introduction of the ClassVersionedObject (Lemmen 2012). The inserted and superseded data are given a time stamp. At any historical moment, the contents of the database can be represented as they were. The generic data type Oid is introduced to provide support for object identifiers in LADM. In principle, the updating, retrieving and management of the database is based on correct source documents, which cannot be changed. The Nigeria land administration has enough information in the maps and plans that can make possible the full implementation of LADM. Land administration is an activity that deals with the enormous amount of data, many of which may be dynamic in nature and may need periodical maintenance. Title registration is time-stamp, the process of obtaining them takes years. Land division, registration, and the amendment also take time. Given this, different classes of LAS have to be versioned to maintain the historical data in the database.

\section{CONCLUSION AND FUTURE WORK}

One of the prime motivations for this paper arises from the need to develop a model that can be used to stimulate the development of software applications. That will accelerate the implementation of proper land administration systems for sustainable development in Nigeria. Having studied conceptualization and the application of LADM as a model that has essential information associated with components of land 
administration. Including those on the land, over water as well as elements above and below the surface of the earth. Having also discovered that there is no blueprint model developed for land administration and management yet in Nigeria. Therefore, there is need to critically analyzed the urgent need for the possible implementation of LADM in this country.

Given this, this paper started with the description of land and land administration in Nigeria. The pre-colonial, colonial and post-colonial era with the organization structure was discussed. This discussion is important to present an understanding of the background of any improvement needed for the LADM implementation in Nigeria. The LADM, ISO 19152 and the packages of LADM was discussed, and the comparison of the different aspects of each package and classes were made with Nigerian land administration and the cadastral system. In the comparison made, it was discovered that there was a concept in all that was similar to LADM in Nigerian land administration. Although, the terminology may not be the same in all cases: Basic Administrative Units package, the land parcel or the property as the basic unit. They may be introduced and properly explain in a version.

Consequently, the model can be adopted into the Nigerian land administration system by mapping in some of the concepts of LADM, having discovered that the standard is suitable for the country. Our net research will be on how to develop an LADM country profile for the country. This paper, however, serves as the foundation for defining the country profile.

\section{REFERENCES}

Atilola, O. ( 2010). Land Administration Reform Nigerian: Issues And Prospects. FIG Congress 2010 Facing the Challenges - Building the Capacity. Sydney, Australia,

Babalola, S. O., T. L. Choon, A. A. Rahman, W. Ayeni and G. Ajayi (2015). An Analysis of 3D Situation as a Prospect for (LADM) in Nigeria: A Malaysian Initiative. International Conference on Science Engineering and social science. UTM Skudai, Johor Bahru, Malaysia.

Chigbu, U. E. and M. Klaus (2013). Insecurity-Generating System of Land Tenure and its Impact on Rural Development: Evidence from Uturu, Nigeria. FIG Working Week 2013. Abuja, Nigeria.

Choon, T. L. and L. K. Seng (2013). Towards a Malaysian Multipurpose 3D Cadastre based on the Land Administration Domain Model (LADM) An Empirical study. 5th Land Administration Domain Model Workshop. Kuala Lumpur, Malaysia: 109-132.

Dale, P. and J. D. McLaughlin (1999). Land Administration System. UK, Oxford University Press.

Dinao, T. and S. Coetzee ( 2013). "Application of the Land Administration Domain Model to the City of Johannesburg Land Information System." South African Journal of Geomatics 2(3).

Fadahunsi, J. T. (2011). Role of Geo-Information Technology in Land Administration in Nigeria. 46th Annual General Meeting and Conference of the Nigerian Institution of Surveyors, held between May 2011. Calabar Nigeria.

Jürg Kaufmann and D. Steudler (1998). Cadastral 2014 with the Working Group 1 of FIG Commission 7, FIG.

Lemmen, C. (2012). A Domain Model for Land Administration. Ph.D. PhD thesis, Technische Universiteit Delft The Netherland.
Lemmen, C. and P. V. Oosterom (2013). The Land Administration Domain Model Standard. 5th Land Administration Domain Model Workshop. Kuala Lumpur, Malaysia.

Mabogunje, A. L. (2007). "Land reform in Nigeria: progress, problems \& prospects." Chairman Technical committee on Land reform.

Njepuome., A. P. C. (2011). Cadastra Land Imformation in Nigeria. Workshop on New Developments in Cadastres, Narobi, Kenya.

Oboli, C. E. and A. O. Akpoyoware (2010). Reform in Cadastre and Land Administration in Nigeria-Coping with Challenges in Development. FIG Congress 2010 Facing the Challenges Building the Capacity. Sydney, Australia.

Oosterom, P. V., L. Christiaan and U. Harry (2013). ISO 19152 2012, Land administration domain model published by ISO. FIG Working Week 2013.Environment for Sustainability. Abuja, Nigeria.

Oosterom, P. V., C. Lemmen, T. Ingvarsson, P. v. d. Molen, H. Ploeger, W. Quak, J. Stoter and J. Zevenbergen (2006). "The core cadastral domain model." Computers, Environment and Urban Systems 30(5): 627-660.

Oosterom, P. V., C. Lemmen and H. Uitermark (2012). Land Administration Standardization with a focus on Evidence from the Field and Processing of Field Observations1. FIG Working Week 2012 Knowing to manage the territory, protect the environment, evaluate the cultural heritage. Rome, Italy, 6-10 May 2012.

Siejka, M., M. Slusarski and M. Zygmunt (2014). "3D+time Cadastre, the possibility of implementation in Poland." Survey Review 46( 335): 79-89.

Siriba, D. N. and J. N. Mwenda (2013). Towards Kenya's Profile of the Land Administration Domain Model LADM. 5th Land Administration Domain Model Workshop. Kuala Lumpur, Malaysia.

Zulkifli, N. A., A. A. Rahman and P. V. Oosterom (2013). Developing 2D and 3D Cadastral Registration System based on LADM illustrated with Malaysian Cases. 5th Land Administration Domain Model Workshop. Kuala Lumpur, Malaysia.

\section{BIOGRAPHICAL NOTES}

Babalola Sunday Oyetayo is a registered Surveyor of the Federal Republic of Nigeria; He has B.Tech in surveying in 1999 and M.Tech in Surveying and Geoinformatics in 2009 at Federal University of Technology Yola Nigeria. He worked as a Lecturer from 2002-2011 at the Federal Polytechnics Bauchi and the Federal University of Technology Akure, Nigeria from 2011 to date. Presently, he is a Ph.D. Research Student at the Faculty of Geoinformation and Real Estate, Universiti Teknologi Malaysia. He has some publications to his credit.

Alias Abdul Rahman is a professor at the Department of Geoinformation, Faculty of Geoinformation and Real Estate, Universiti Teknologi Malaysia (UTM), Skudai, Johor in Malaysia. He received a degree in Surveying and Mapping Sciences from North East London Polytechnic, England, The UK in 1987, Postgrad Diploma in GIS from ITC, Netherlands, and MSc in GIS also from ITC, Netherlands. In 2000, he received his Ph.D. degree from University of Glasgow, Scotland, U.K. He currently leads the 3D GIS research group in the Faculty. 
Tan Liat Choon was an Assistant Director of Survey at Department of Survey and Mapping Malaysia (JUPEM) since 16 July 2003. He was attached as an Assistant Director with Malaysian Centre for Geospatial Data Infrastructure (MaCGDI). He was also with Database Section, JUPEM. He studied on "Towards Developing a Three-dimensional Cadastre for Three dimensional Property Rights in Malaysia" as his Ph.D. thesis. His research interests are 3D property legislation in Cadastral Survey and Mapping Registration System and Land Registration System. He holds MSc. Degree in Land Administration and Development (2002), BSc. Degree in Land Survey (1998), and a Diploma in Land Survey (1996) all from Universiti Teknologi Malaysia (UTM), and also Certificated in Land Survey (1993) from Politeknik Kuching Sarawak, Malaysia.He is presently a senior lecturer at the Faculty of Geoinformation and Real Estate, Universiti Teknologi Malaysia.

Peter van Oosterom obtained MSc in Technical Computer Science in 1985 from the Delft University of Technology, the Netherlands. In 1990, he received a Ph.D. from Leiden University for his thesis 'Reactive Data Structures for GIS'. From 1985 until 1995 he worked at the TNO-FEL laboratory in The Hague, the Netherlands as a computer scientist. From 1995 until 2000 he was senior information manager at the Dutch Cadaster, where he was involved in the renewal of the Cadastral (Geographic) database. Since 2000, he is a professor at the Delft University of Technology, Faculty of Architecture and the Built Environment, Department OTB, and head of the 'GIS Technology' Section. He is the current chair of the FIG working group on '3D-Cadastres' (Commissions 3 and 7). He is one of the co-editors of ISO 19152 (together with Lemmen and Uitermark).

\section{CONTACTS}

Babalola Sunday Oyrtayo |Alias Abdul Rahman |Tan Liat

\section{Choon}

Universiti Teknologi Malaysia

3D GIS Research Lab

Faculty of Geoinformation and Real Estate

81310 UTM Skudai, Johor, MALAYSIA

Phone: +60173584355 |+60137490452 |+60164975551

omooroloba@gmail.con | alias@utm.my|tlchoon@utm.my

\section{Peter van Oosterom}

Delft University of Technology

Faculty of Architecture and the Built Environment

Department OTB, GIS Technology Section

P.O. Box 5030

2600 GA Delft

The Netherlands

Phone: +31 152786950

E-mail: P.J.M.vanOosterom@tudelft.nl

Website: www.gdmc.nl 